\title{
Capítulo 3 - Quem são as professoras e quem são os alunos atendidos nas Salas de Recursos Multifuncionais
}

\author{
Leila Regina d'Oliveira de Paula Nunes \\ Carolina Rizzotto Schirmer \\ Stefhanny Paulimineytrick Nascimento Silva \\ Maria Gabriela Lopes Araújo
}

\section{SciELO Books / SciELO Livros / SciELO Libros}

NUNES, L. R. O. P. N., et al. Quem são as professoras e quem são os alunos atendidos nas Salas de Recursos Multifuncionais. In: NUNES, L. R. O. P., and SCHIRMER, C. R., orgs. Salas abertas: formação de professores e práticas pedagógicas em comunicação alternativa e ampliada nas salas de recurso multifuncionais [online]. Rio de Janeiro: EDUERJ, 2017, pp. 63-86. ISBN: 978-85-7511-4520. Available from: doi: 10.7476/9788575114520.005. Also available in ePUB from: http://books.scielo.org/id/xns62/epub/nunes-9788575114520.epub.

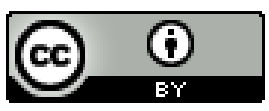

All the contents of this work, except where otherwise noted, is licensed under a Creative Commons Attribution 4.0 International license.

Todo o conteúdo deste trabalho, exceto quando houver ressalva, é publicado sob a licença Creative Commons Atribição 4.0.

Todo el contenido de esta obra, excepto donde se indique lo contrario, está bajo licencia de la licencia $\underline{\text { Creative Commons }}$ Reconocimento 4.0. 


\title{
Capítulo 3 - Quem são as professoras e quem são os alunos atendidos nas Salas de Recursos Multifuncionais
}

\author{
Leila Regina d'Oliveira de Paula Nunes ${ }^{1}$ \\ Carolina Rizzotto Schirmer ${ }^{2}$ \\ Stefhanny Paulimineytrick Nascimento Silva ${ }^{3}$ \\ Maria Gabriela Lopes Araújó
}

\section{Introdução}

Educadores e pesquisadores em Educação e Educação Especial concordam que a perspectiva atual da inclusão exige o repensar da escola, com o objetivo de proporcionar um ensino de qualidade para todos os alunos, sem exceção. Para que isso ocorra, a formação de professores torna-se essencial nesse processo, e várias são as ações políticas e os estudos voltados para a atua-

1 Professora titular da Faculdade de Educação e do Programa de Pós-Graduação em Educação da UERJ. E-mail: leilareginanunes@terra.com.br

2 Professora adjunta da Faculdade de Educação da UERJ. E-mail: ead.carolina@gmail. com

3 Mestranda em Educação pelo Programa de Pós-Graduação em Educação da UERJ. E-mail: stefhannyp@gmail.com

4 Graduanda em Pedagogia pela UERJ. E-mail: gabiaraujo11@hotmail.com 
ção tanto em sala de aula como no atendimento educacional especializado (Martins, 2003; Oliveira, 2003; Lauro et al., 2003; Gomes e Barbosa, 2006; Pelosi, 2008; Pletsch, 2009; Bersch, 2009; Nunes, 2009; Lourenço, 2012; Veltrone e Mendes, 2011).

Para que se possa garantir a acessibilidade do aluno com deficiência e Transtorno do Espectro Autista (TEA) ao conhecimento, ao espaço físico, às interações e à comunicação, é necessário que os professores de Salas de Recursos Multifuncionais (SRM), principais interlocutores e modelos, tenham conhecimento sobre a Tecnologia Assistiva (TA) e, especialmente, sobre a Comunicação Alternativa e Ampliada (CAA). Porém, para que a TA e a CAA façam parte do cotidiano da SRM e da escola, é fundamental que os professores da Educação Especial que trabalham com os alunos sejam capazes não apenas de implementar seus recursos, como também de favorecer interações ricas em comunicação. Esse conhecimento exige que, em sua formação, os professores sejam levados a refletir e a repensar sua prática, assim como trabalhar colaborativa e criativamente (Schirmer, 2012).

A formação continuada em serviço de professores constituiu-se como tema e foi o objeto desta pesquisa, que teve como objetivos planejar, implementar e avaliar a eficácia do programa de formação continuada em serviço de professores sobre TA, com ênfase na CAA, por intermédio de uma metodologia problematizadora, a fim de favorecer as interações sociais e o uso desses recursos por alunos com deficiência e TEA. Tanto para o planejamento quanto para a implementação, foi essencial conhecer as professoras de SRM e seus alunos, assim como envolvê-los no planejamento do curso. Por isso, este capítulo apresenta quem são as professoras das SRM e quem são os alunos atendidos por elas.

No início da pesquisa, um questionário e uma ficha foram aplicados a 18 educadoras das SRMs, que aceitaram participar deste projeto. O questionário teve por objetivo traçar o perfil dessa população, e a ficha visava a identificar quem são os alunos atendidos nas SRMs por essas professoras. O questionário, respondido na segunda sessão da pesquisa, realizada no dia 22/05/2013, era composto de 19 questóes abertas e foi respondido na sala da Oficina Vivencial do Instituto Helena Antipoff. Todos os respondentes eram do sexo feminino. 
A seguir, serão apresentados em forma de gráfico os dados coletados.

Gráfico 1 - Idade das Professoras

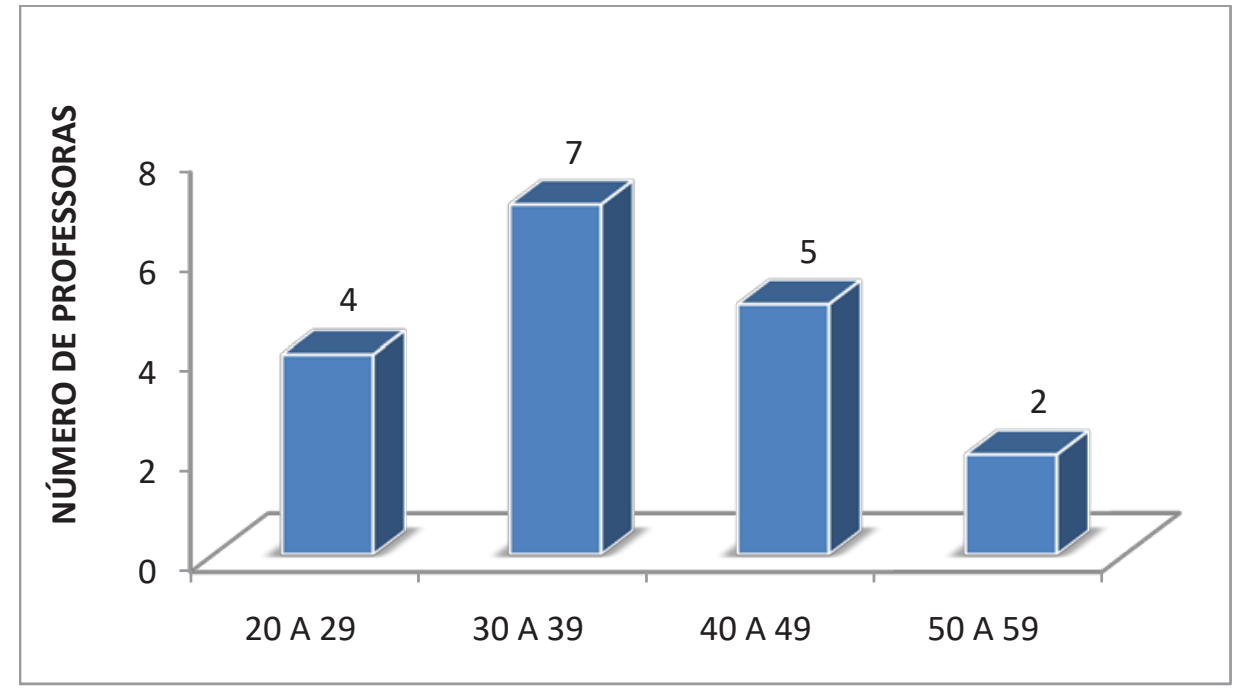

Trinta e nove por cento das professoras tinham a idade entre 30 e 39 anos e, em 28\%, a idade variava entre 40 e 49 anos.

Gráfico 2 - Tempo de magistério nas escolas da Secretaria Municipal de Educação

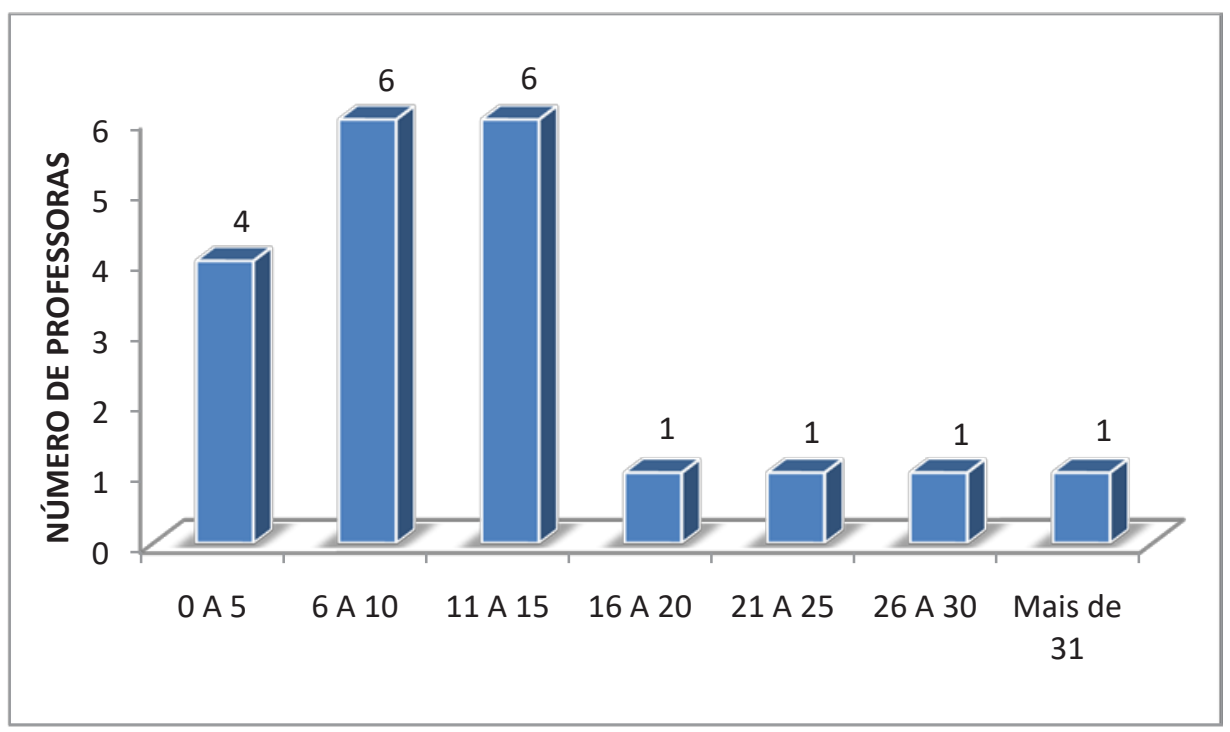


O tempo de magistério de $67 \%$ das respondentes variou entre seis e 15 anos.

Gráfico 3 - Tempo de atuação em Educação Especial

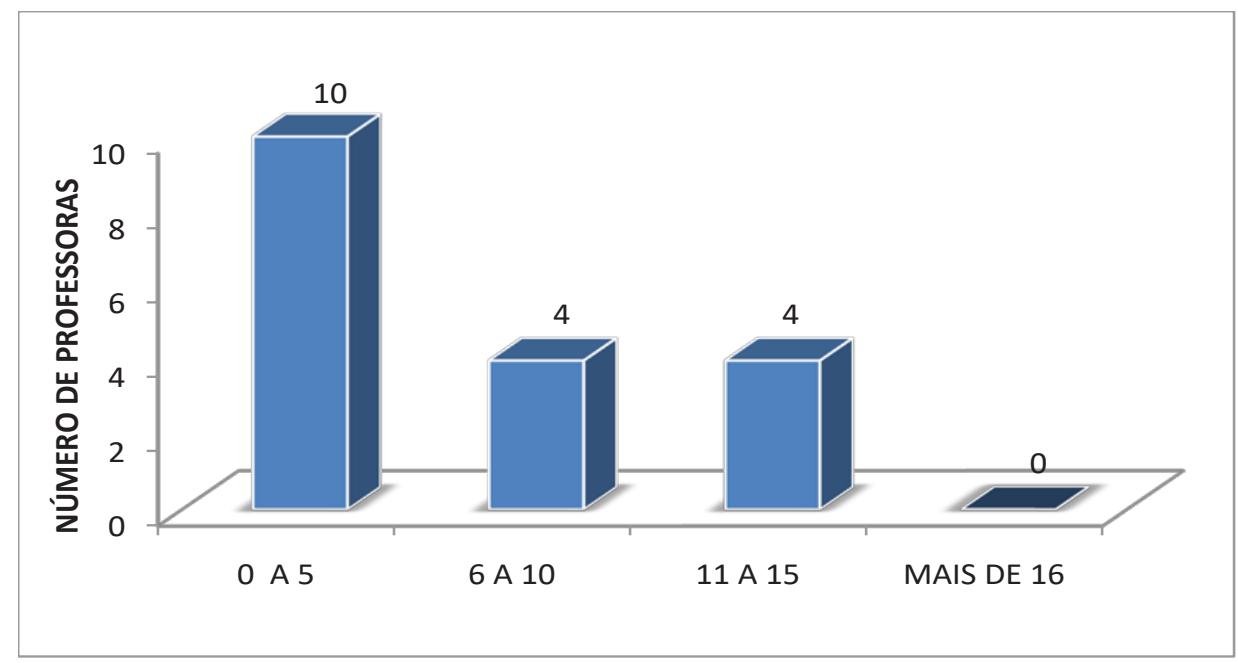

Cinquenta e seis por cento das professoras trabalhavam em um período de cinco anos, ou menos, em Educação Especial.

Gráfico 4 - Tempo de atuação nas Salas de Recursos Multifuncionais

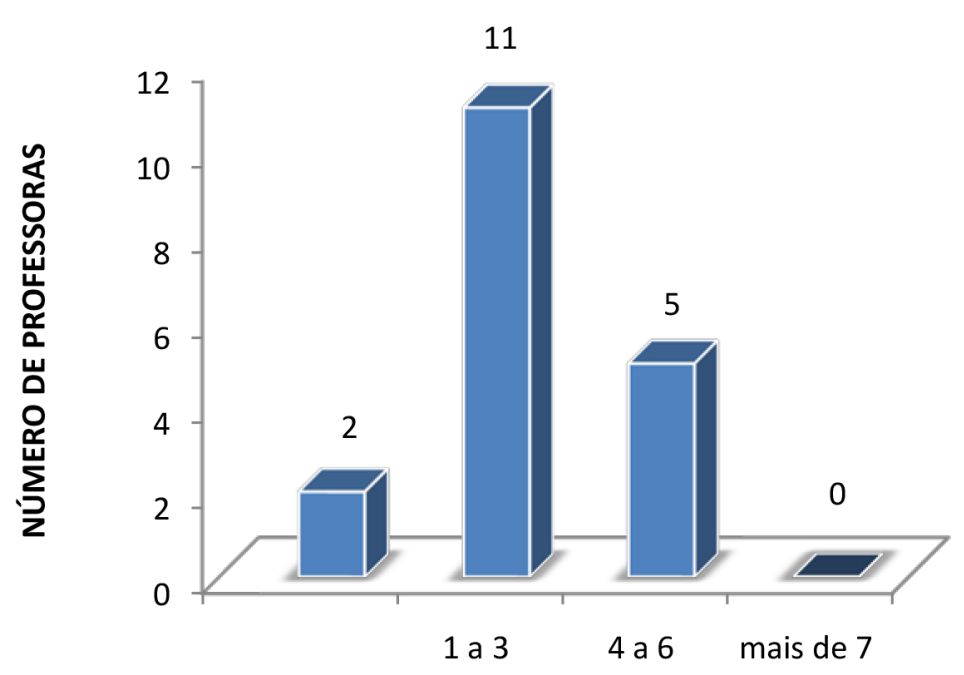


Setenta e dois por cento das professoras trabalhavam nas SRMs por um período igual ou menor que três anos.

Gráfico 5 - Funções exercidas anteriormente à SRM

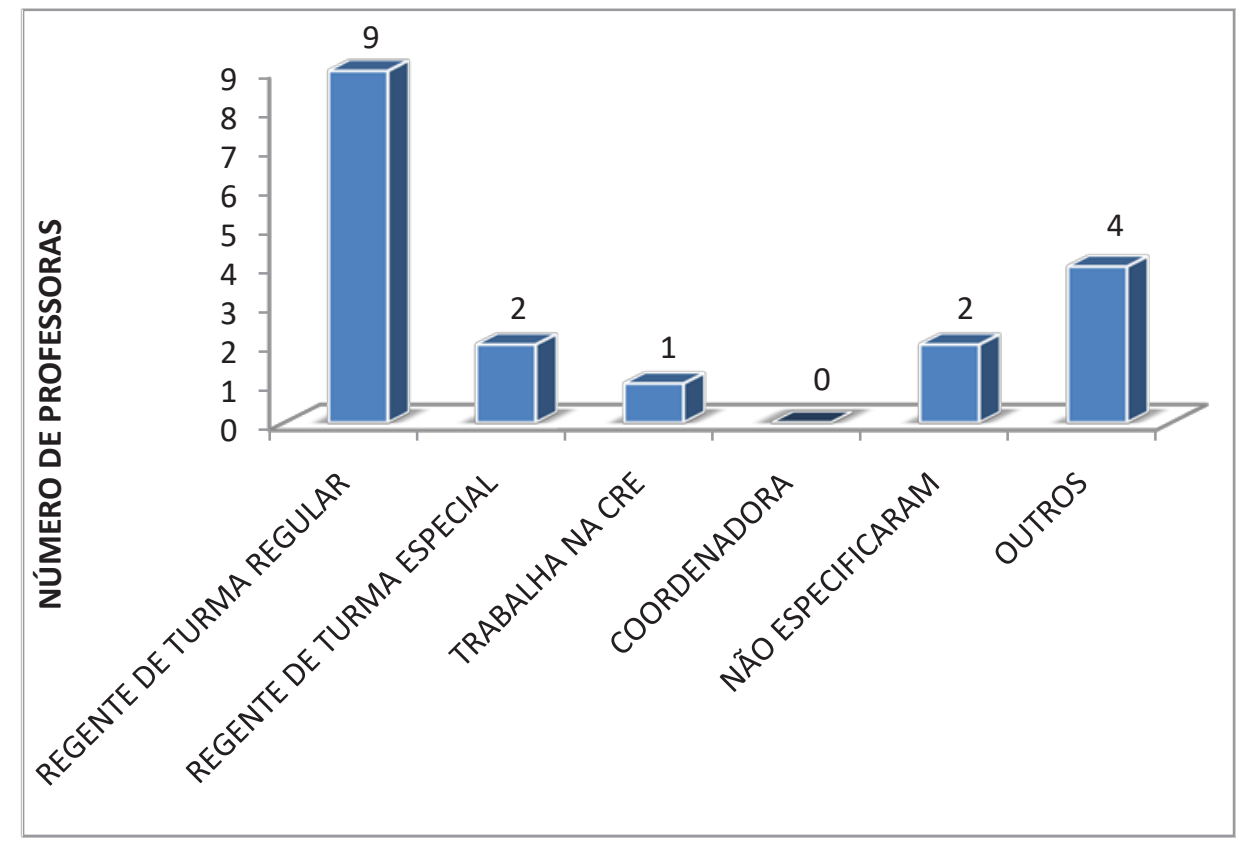

Cinquenta por cento atuavam como regente de turma comum antes da SRM. 
Gráfico 6 - Outras funções exercidas atualmente pelas professoras

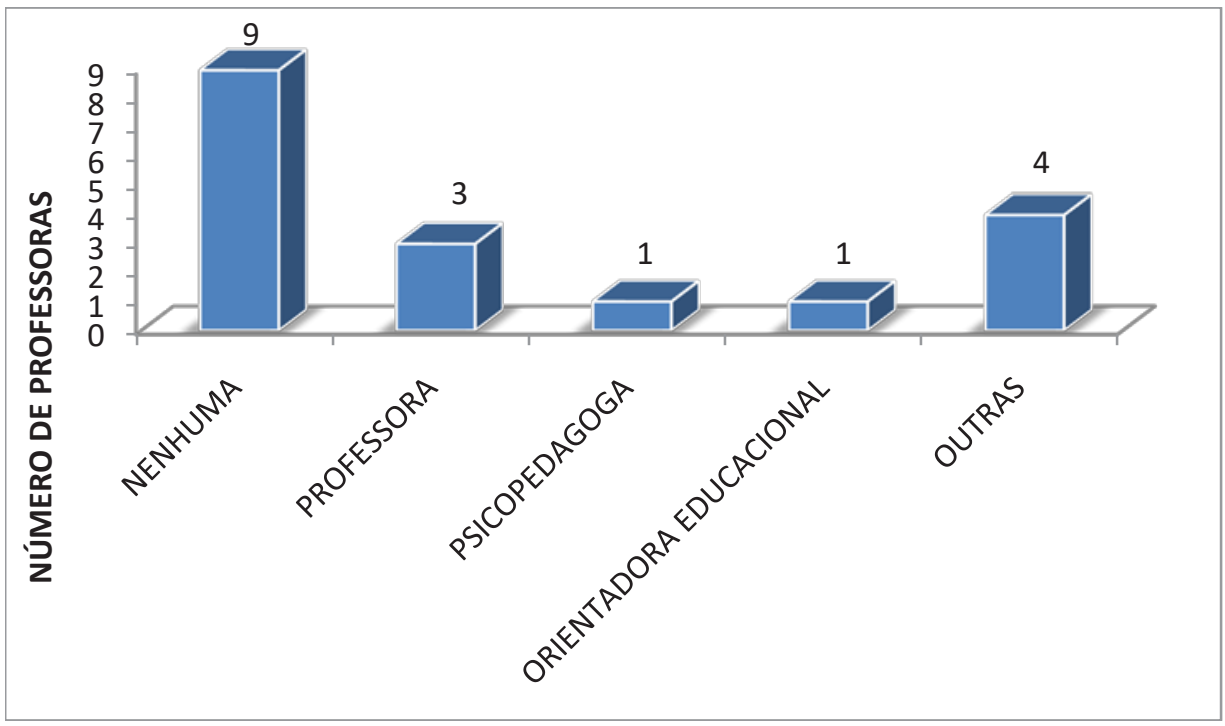

Cinquenta por cento das professoras não exerciam outra função além da SRM. 
Gráfico 7 - Graduação cursada

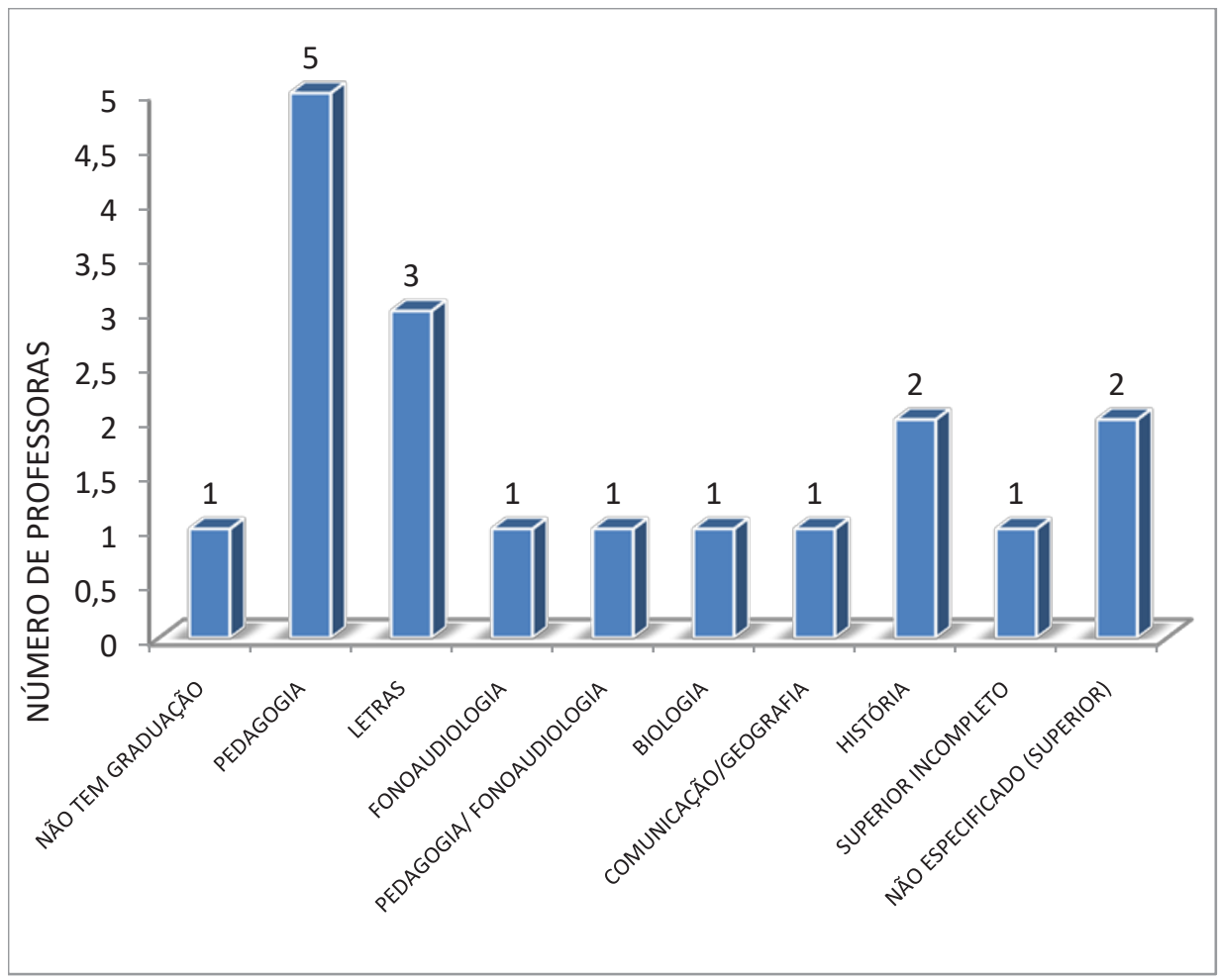

Vinte e oito por cento das participantes haviam cursado graduação em Pedagogia. Apenas 6\% das professoras não possuíam graduação. 
Gráfico 8 - Ano de conclusão da graduação

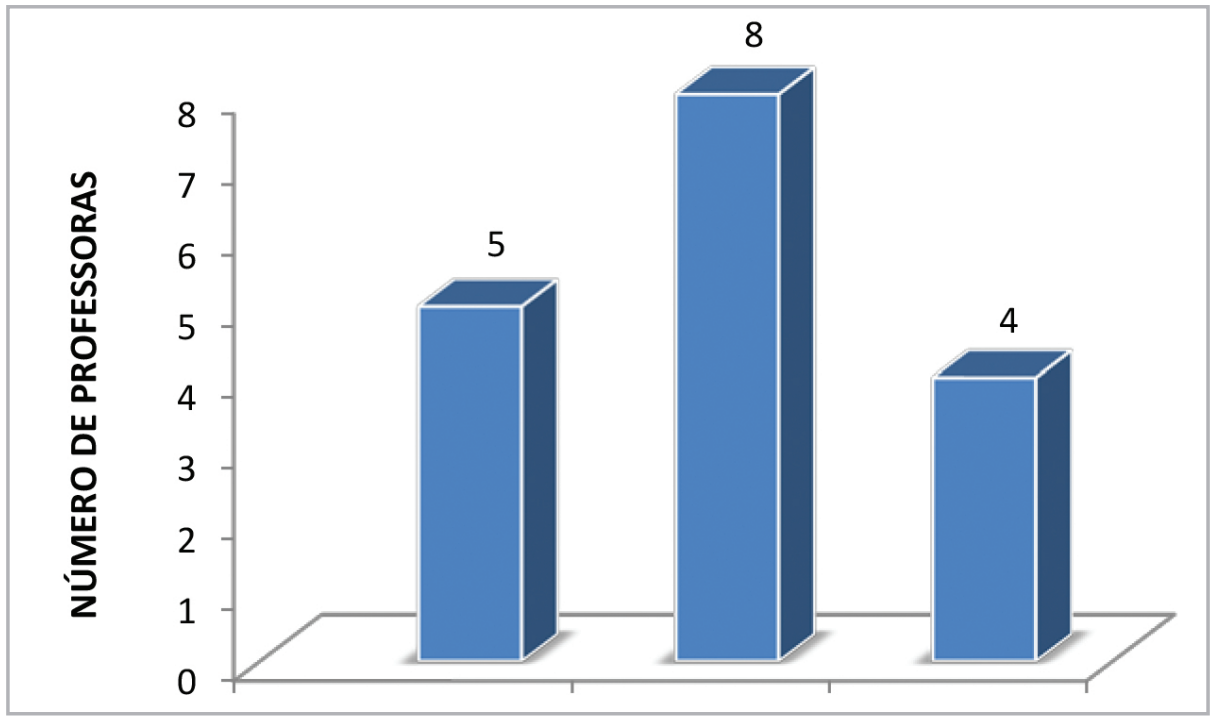

Quarenta e quatro por cento das professoras concluíram a graduação entre 2006 e 2010.

Gráfico 9 - Curso de especialização

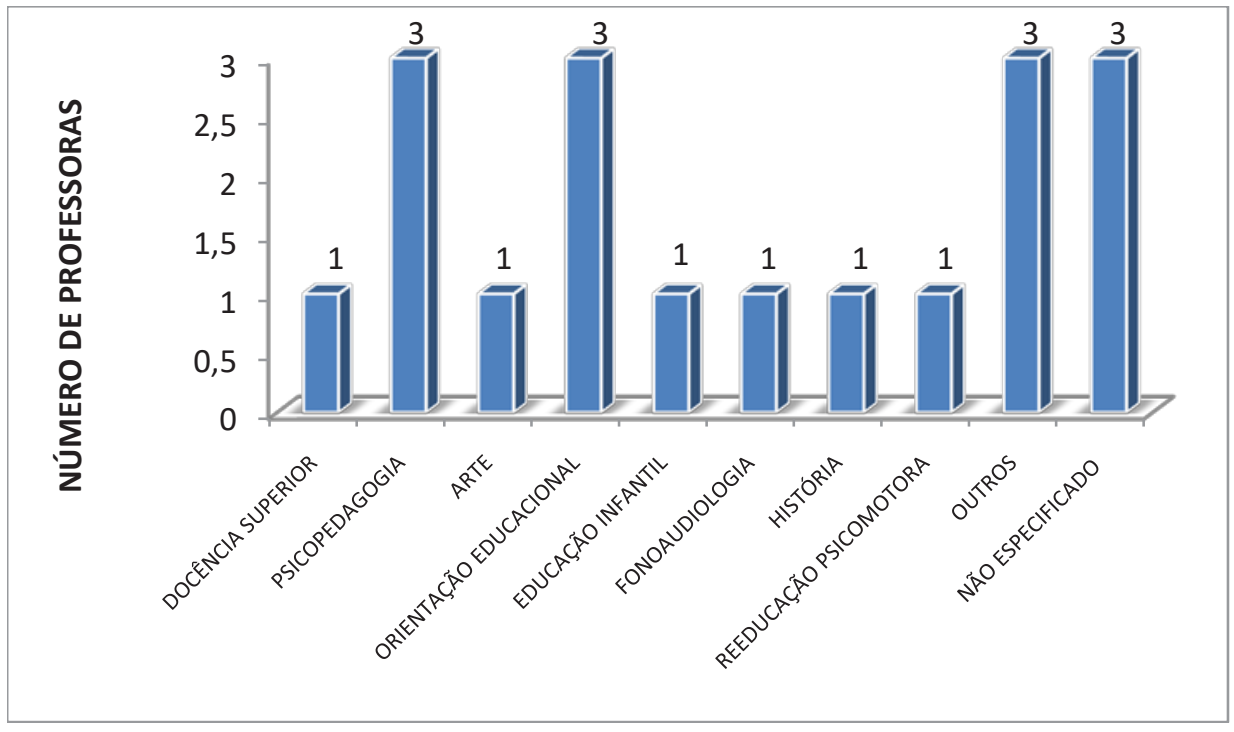


Cem por cento das participantes frequentaram cursos de especialização. Trinta por cento cursaram Psicopedagogia ou Orientação Educacional. Gráfico 10 - Cursos de mestrado e doutorado

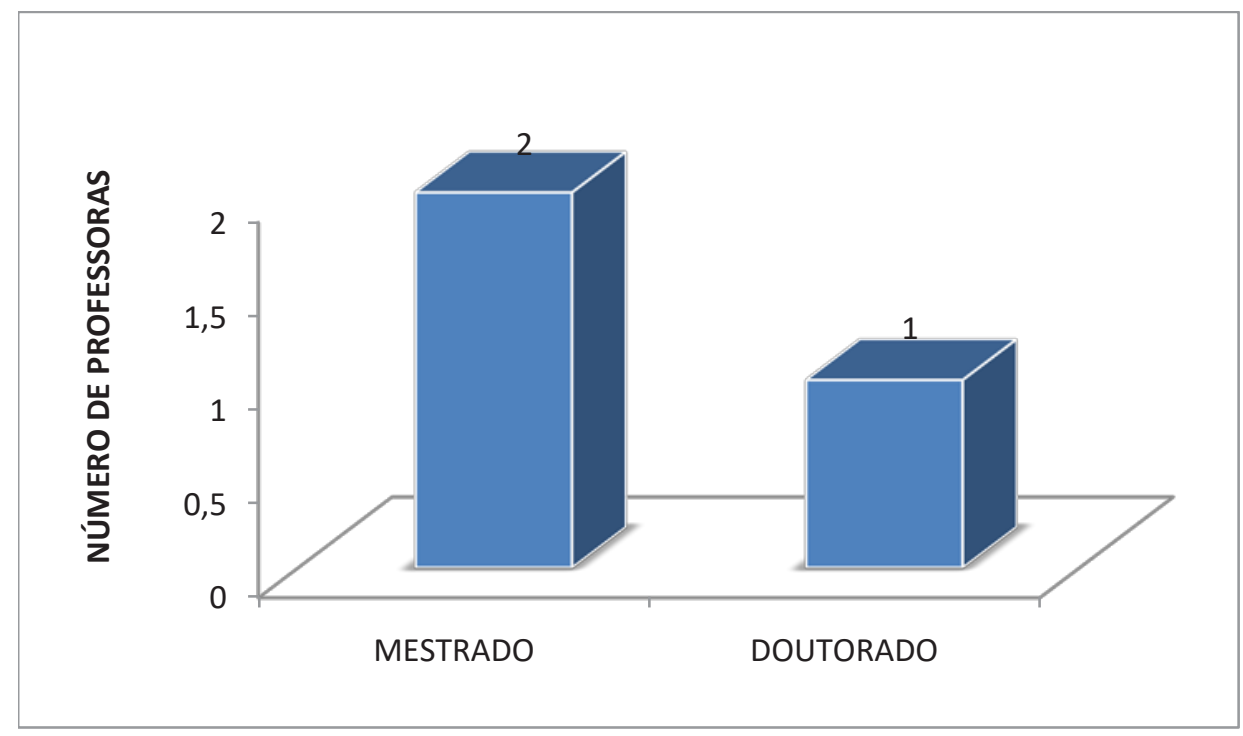

Entre as 18 participantes, apenas duas tinham mestrado e uma cursava doutorado.

Gráfico 11 - Ano de conclusão do curso sobre Comunicação Alternativa e Ampliada

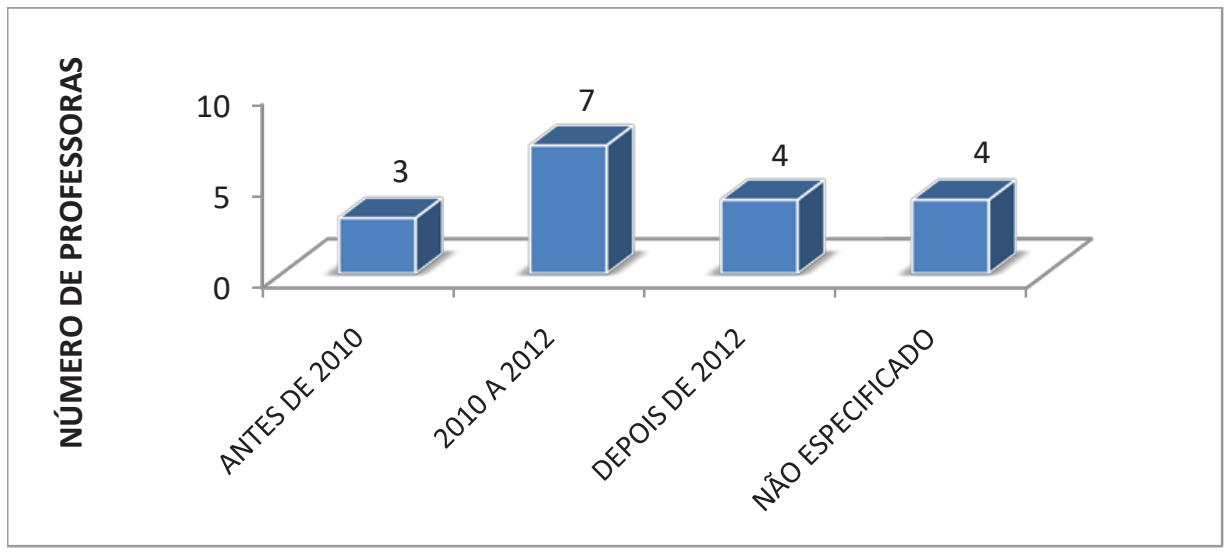


Todas as professoras já haviam frequentado curso sobre Comunicação Alternativa e Ampliada. Trinta e nove por cento no período compreendido entre 2010 e 2012.

Gráfico 12 - Duração do curso sobre Comunicação Alternativa e Ampliada

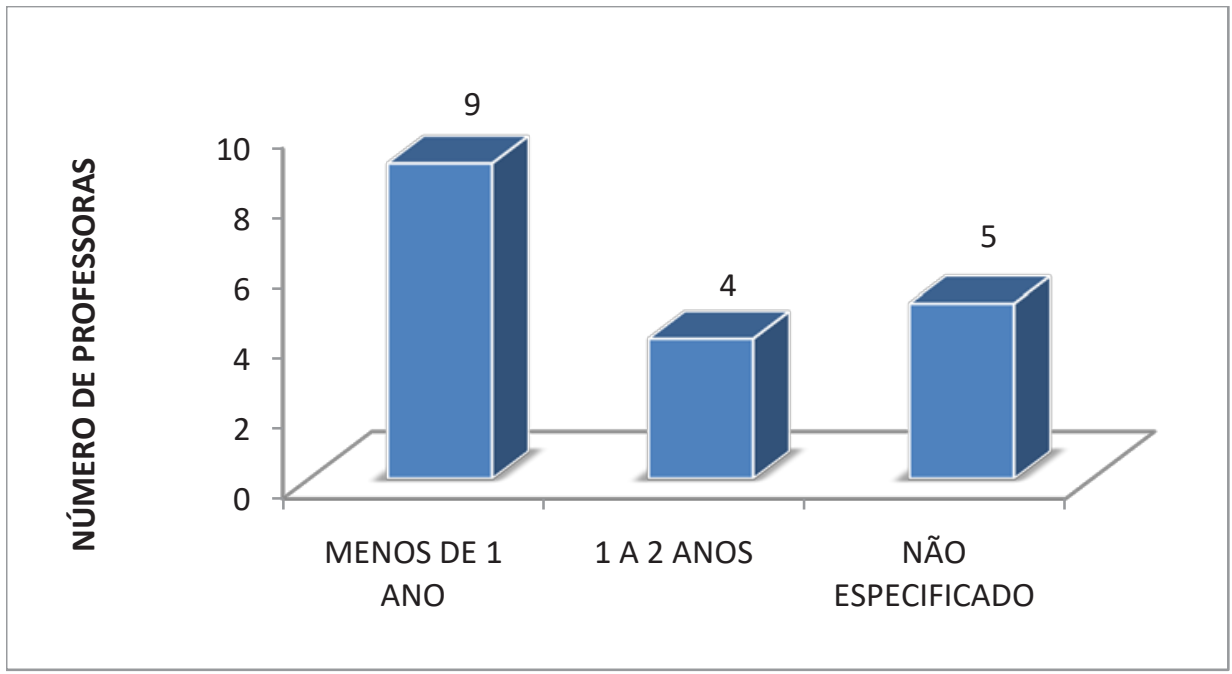

Cinquenta por cento das professoras completaram o curso sobre CAA em menos de um ano.

Gráfico 13 - Instrutores dos cursos de CAA

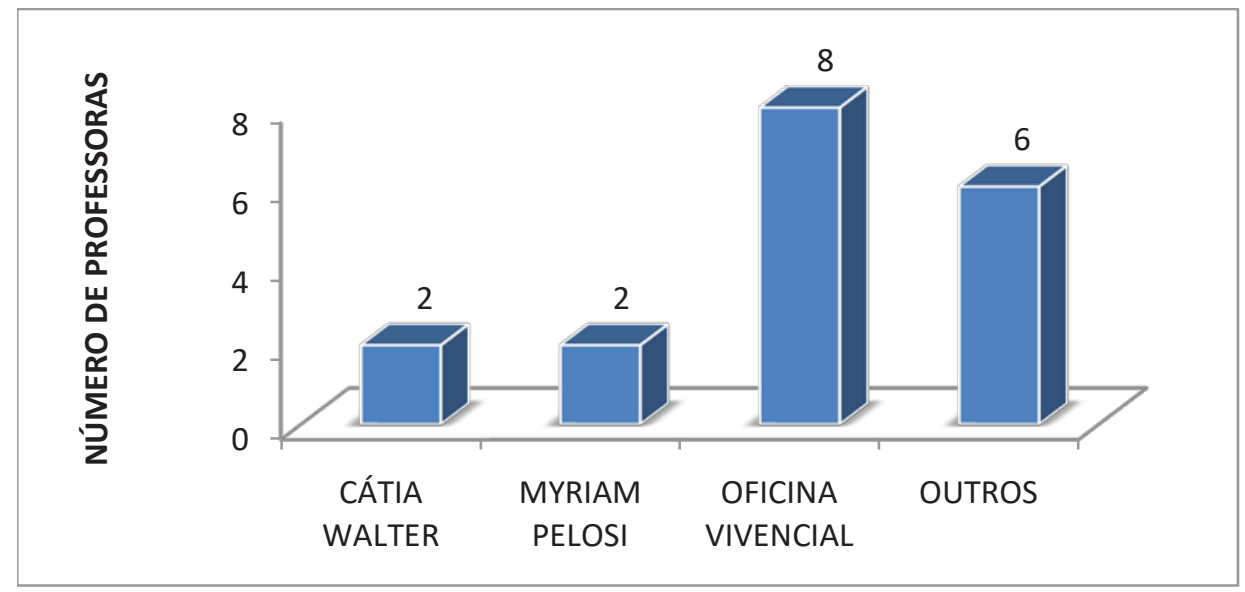


Quarenta e quatro por cento das participantes frequentaram o curso de CAA ofertado pelas professoras da OV do IHA.

Gráfico 14 - Frequência a curso de formação em Educação Especial nos últimos três anos

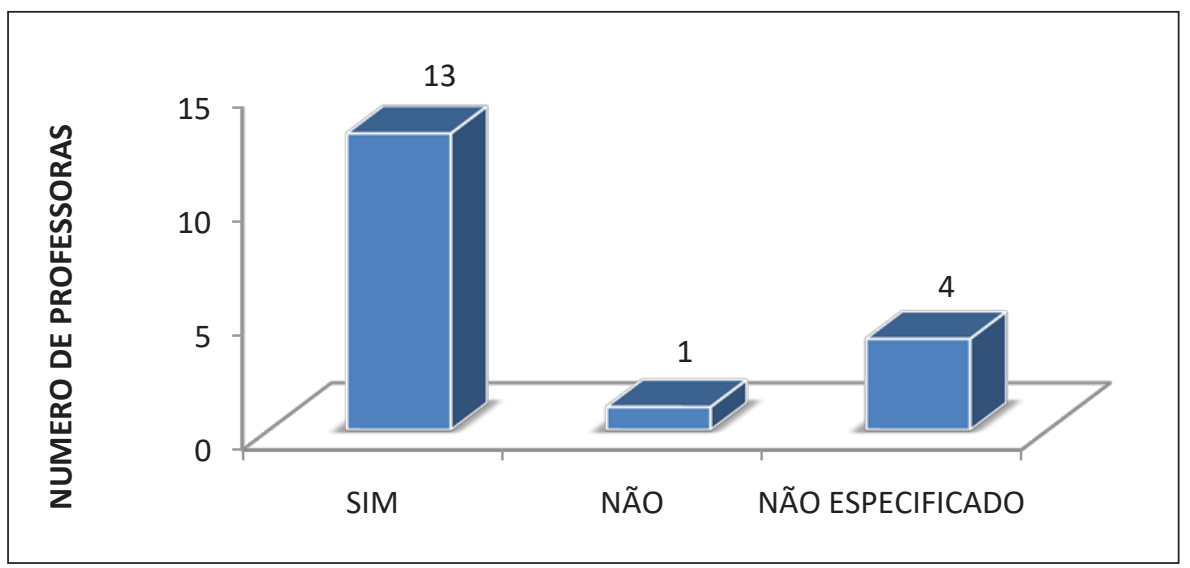

Setenta e dois por cento das professoras frequentaram curso de formação em Educação Especial nos últimos três anos.

Gráfico 15 - Temas dos cursos de formação em Educação Especial nos últimos três anos

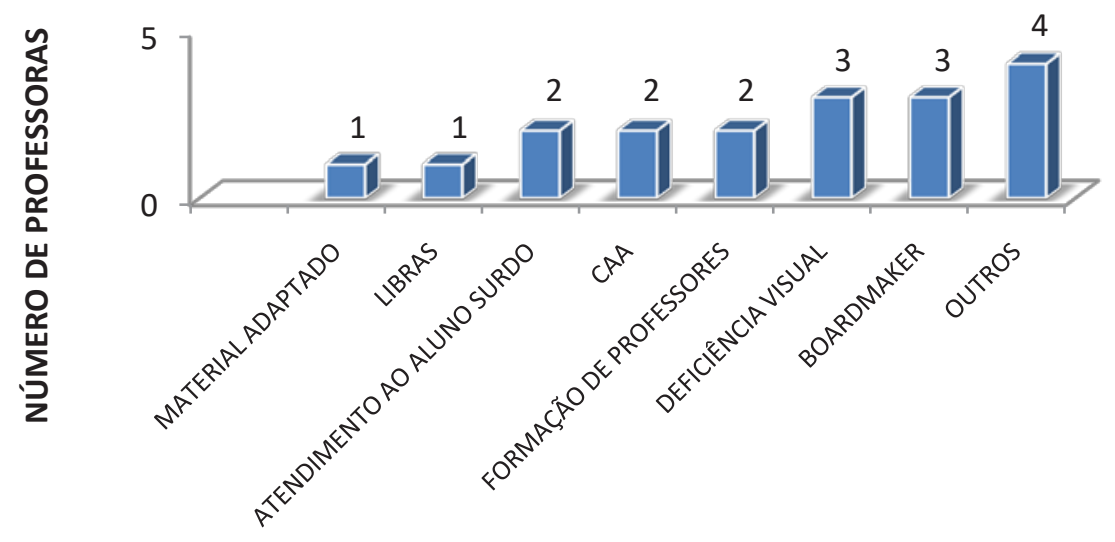


Vinte e oito por cento das participantes frequentaram cursos ligados à CAA e ao software Boardmaker.

Gráfico 16 -Frequência em eventos científicos em Educação Especial nos últimos dois anos

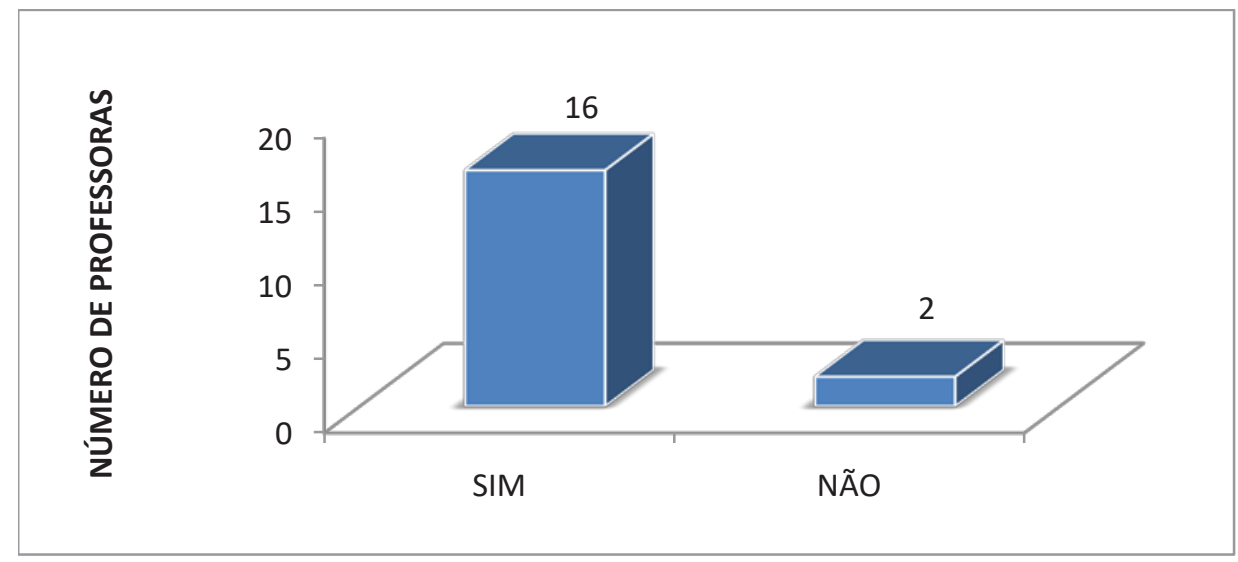

Oitenta e nove por cento das professoras frequentaram eventos científicos em Educação Especial nos últimos dois anos.

Gráfico 17 - Eventos científicos em Educação Especial, nos últimos dois anos, dos quais participaram as professoras

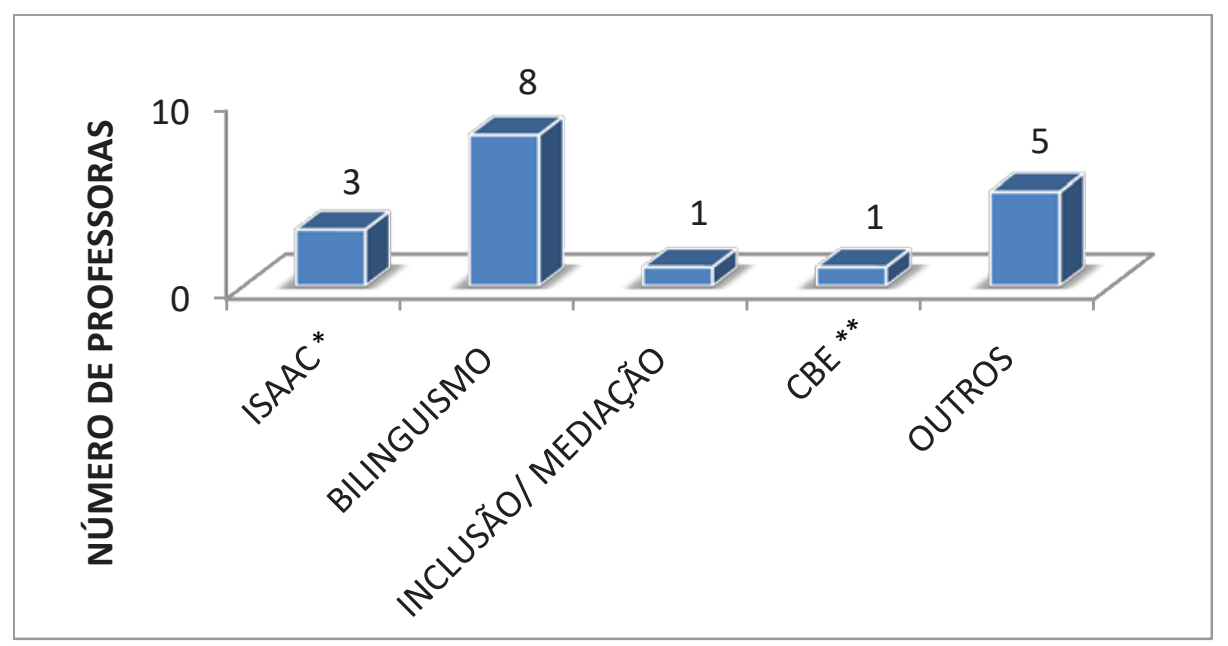

* ISAAC - International Society for Argumentative and Alternative Comunication

** CBE - Congresso Brasileiro de Educação 
Apenas $17 \%$ das professoras frequentaram eventos científicos ligados à CAA.

Gráfico 18 - Temas das leituras feitas pelas participantes

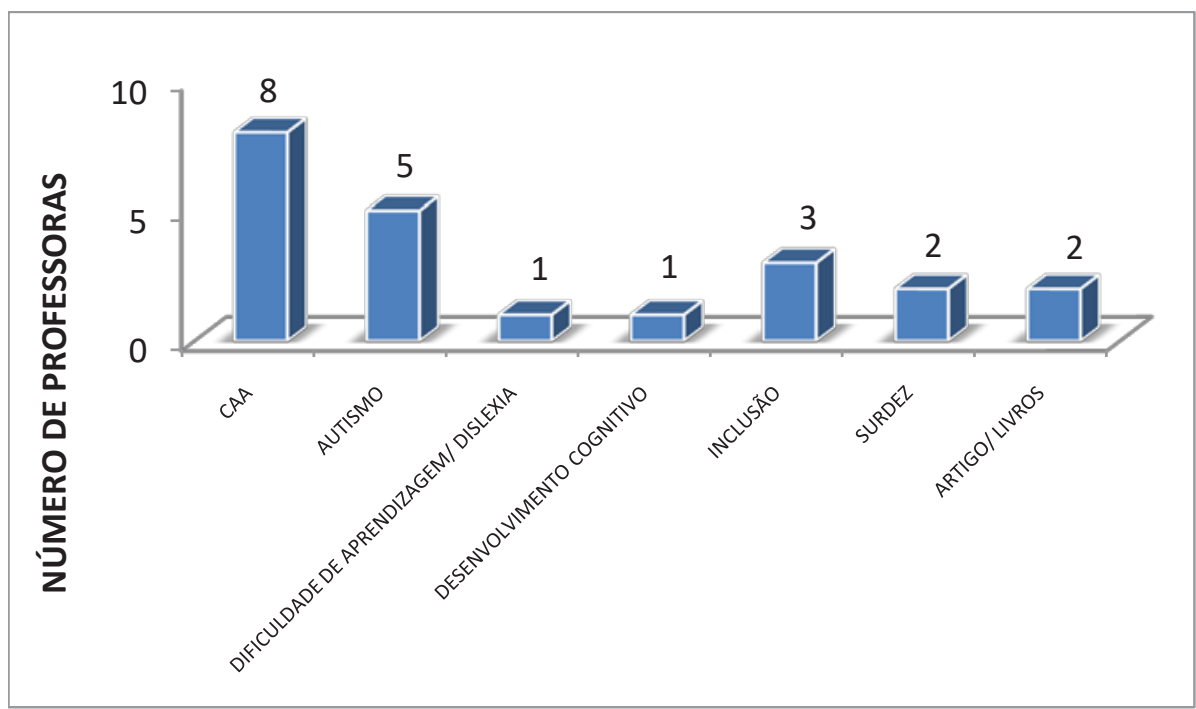

Quarenta e quatro por cento das participantes reportaram leituras sobre Comunicação Alternativa e Ampliada, e 27,5\% das participantes realizaram leitura sobre o Transtorno do Espectro Autista.

\section{Quem são os alunos atendidos por essas professoras}

Uma ficha contendo 12 itens foi preenchida por 17 professoras, informando as características dos 262 alunos atendidos por elas nas SRMs entre 2015 e 2016. Os dados coletados serão apresentados a seguir.

As 17 professoras atendem, em média, 15 alunos em suas SRMs, e a variação é de seis a 24 alunos.

No gráfico19, apresenta-se a informação sobre o sexo dos alunos atendidos. 
Gráfico 19 - Sexo dos alunos atendidos

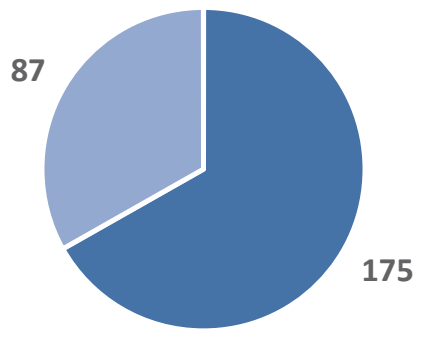

- Masculino - Feminino

Do total de 262 alunos, $67 \%$ são do sexo masculino.

No gráfico 20, apresenta-se a idade dos alunos.

Gráfico 20 - Idade dos alunos

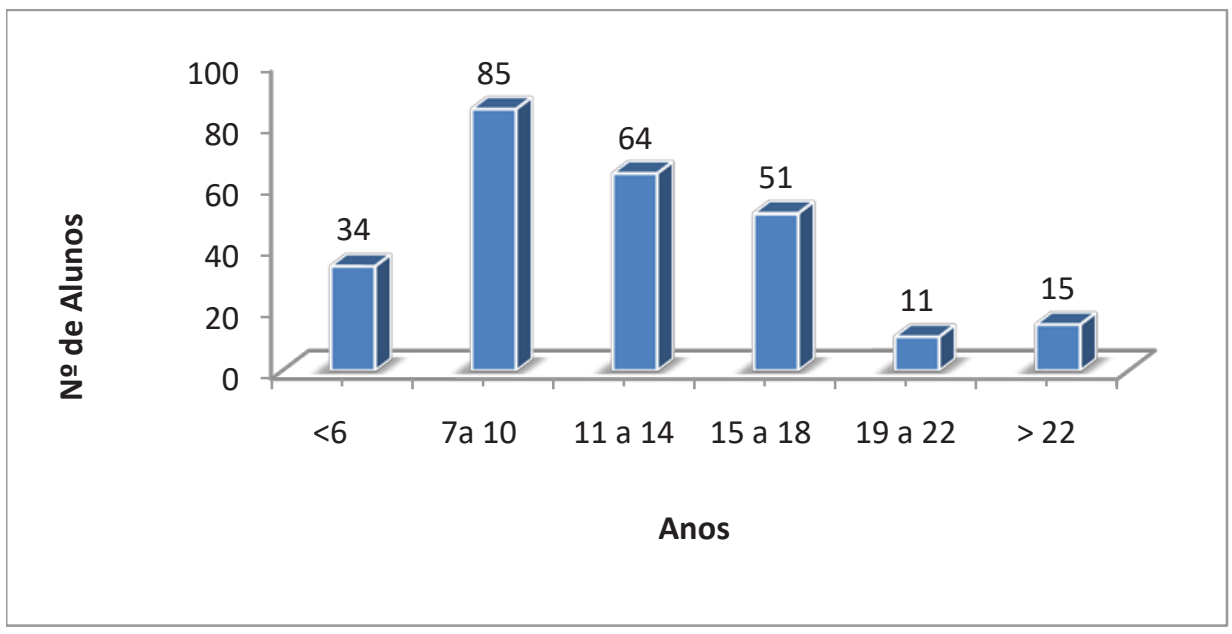

Trinta e dois por cento dos alunos têm idade entre sete e 10 anos.

No gráfico 21, identifica-se o tipo de deficiência dos alunos. 
Gráfico 21 - Tipo de deficiência dos alunos

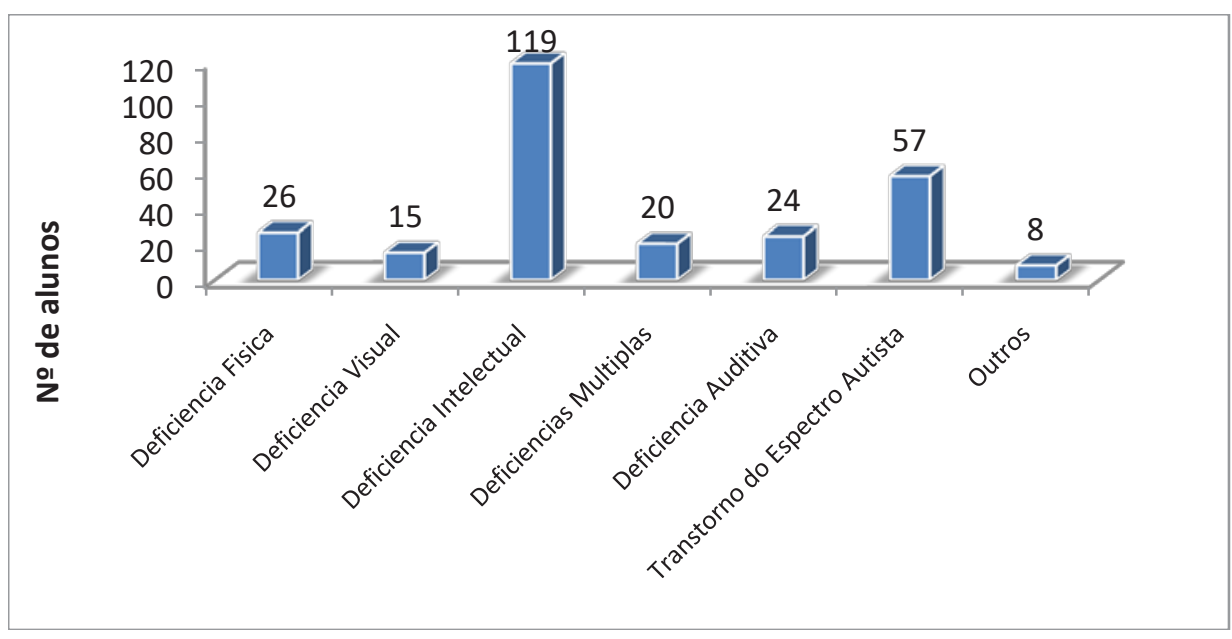

Observa-se que 45\% dos alunos atendidos apresentam deficiência intelectual e $22 \%$ apresentam TEA.

No gráfico 22, está apresentada a frequência semanal dos alunos nas Salas de Recursos.

Gráfico 22 - Frequência dos alunos

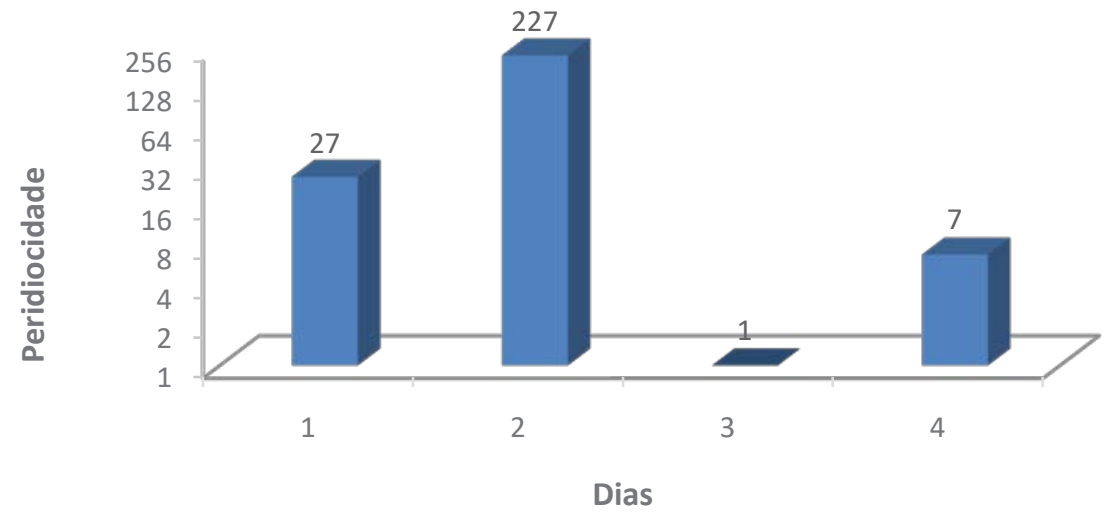

A maioria dos alunos, $87 \%$, é atendida duas vezes por semana nas salas de recursos. 
No gráfico 23, apresenta-se a série escolar desses alunos.

Gráfico 23 - Série escolar dos alunos

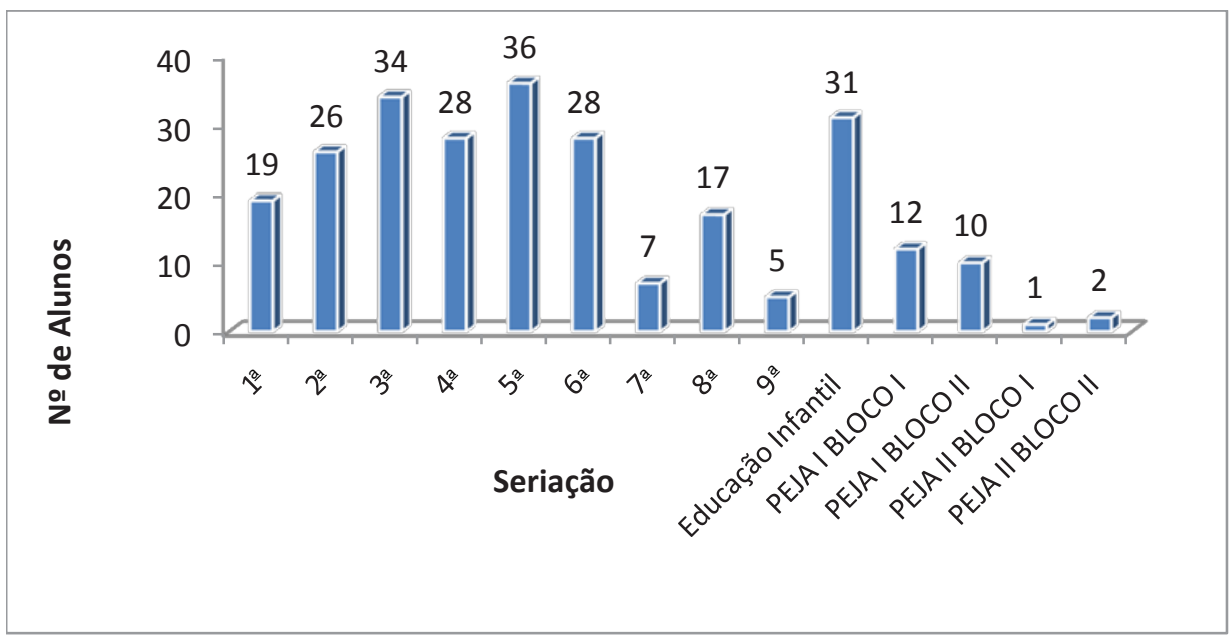

Observa-se que $27 \%$ dos alunos frequentam a $3 .^{\mathrm{a}}$ e a $5 .^{\mathrm{a}}$ séries.

No gráfico 24, mostra-se o número de professoras que contam com estagiário nas Salas de Recursos Multifuncionais.

Gráfico 24 -Número de professoras que contam com estagiário nas salas de recursos

- Sim Não 
Verifica-se que apenas 35\% das professoras contam com a colaboração de estagiário.

No gráfico 25, é exibido o número de alunos considerados assíduos nas sessões ocorridas nas salas de recursos.

Gráfico 25 - Número de alunos considerados assíduos nas sessões nas Salas de Recursos

\section{Assiduidade}

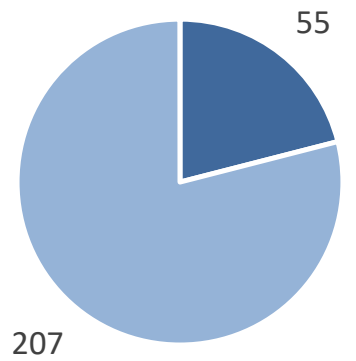

- Não assíduo

Assíduo

Setenta e nove por cento dos alunos atendidos nas sessões nas Salas de Recursos são considerados assíduos por suas professoras.

No gráfico 26, são exibidos os objetivos dos atendimentos ofertados aos alunos pelas professoras das Salas de Recursos. 
Gráfico 26 - Objetivos dos atendimentos ofertados aos alunos pelas professoras das Salas de Recursos

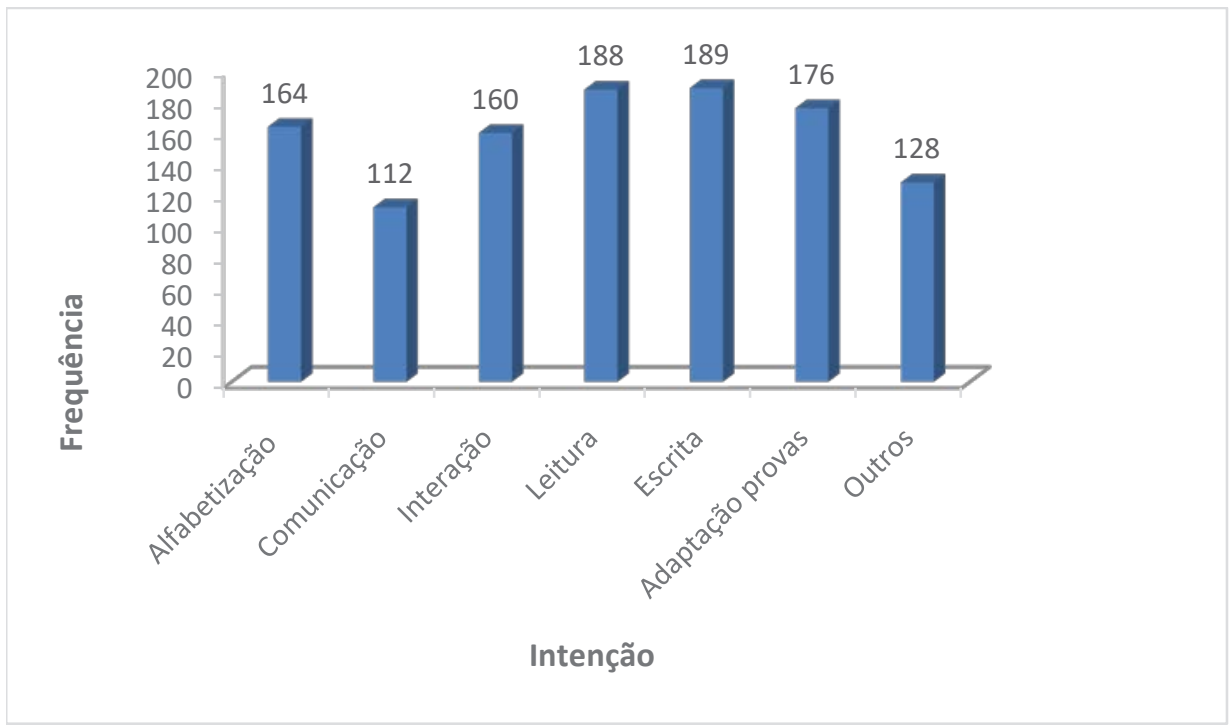

A seguir, no quadro 1, estão listados todos os objetivos categorizados como "Outros" pelas professoras. 
Quadro 1 - Objetivos categorizados como "Outros” pelas professoras

\begin{tabular}{|l|c|}
\hline Objetivos & Número de respondentes \\
\hline Ensino dos conceitos escolares bimestrais & 20 \\
\hline Autonomia nas atividades de vida diária & 11 \\
\hline Braille & 1 \\
\hline Prova individual diferente do ano da turma comum & 1 \\
\hline Organização do material de estudo & 1 \\
\hline Estimulação visual & 1 \\
\hline Conceitos matemáticos & 1 \\
\hline Matemática & 5 \\
\hline História & 1 \\
\hline Ciências & 1 \\
\hline Geografia & 1 \\
\hline Ensino PECS5 & 1 \\
\hline Adaptação do caderno & 2 \\
\hline Adaptação de atividade pedagógica & 1 \\
\hline Adaptação de conteúdo & 1 \\
\hline Raciocínio lógico & 15 \\
\hline Raciocínio lógico-matemático & 2 \\
\hline Percepção & 1 \\
\hline Memorização & 1 \\
\hline Atenção & 1 \\
\hline Concentração & 1 \\
\hline Redução de questões & 3 \\
\hline Figura & 1 \\
\hline Ampliação & 3 \\
\hline Flexibilização curricular & 1 \\
\hline Atividades e recursos & 1 \\
\hline Coordenação motora fina & 3 \\
\hline Coordenação motora & 1 \\
\hline Habilidades cognitivas e não cognitivas & 1 \\
\hline Interpretação de texto & 1 \\
\hline
\end{tabular}

5 Picture Exchange Comunication System 
Alfabetização, leitura e escrita são os objetivos mais frequentes no atendimento ofertado.

No gráfico 27, são apresentados os recursos usados pelas professoras nas Salas de Recursos.

Gráfico 27 - Recursos usados pelas professoras nas Salas de Recursos

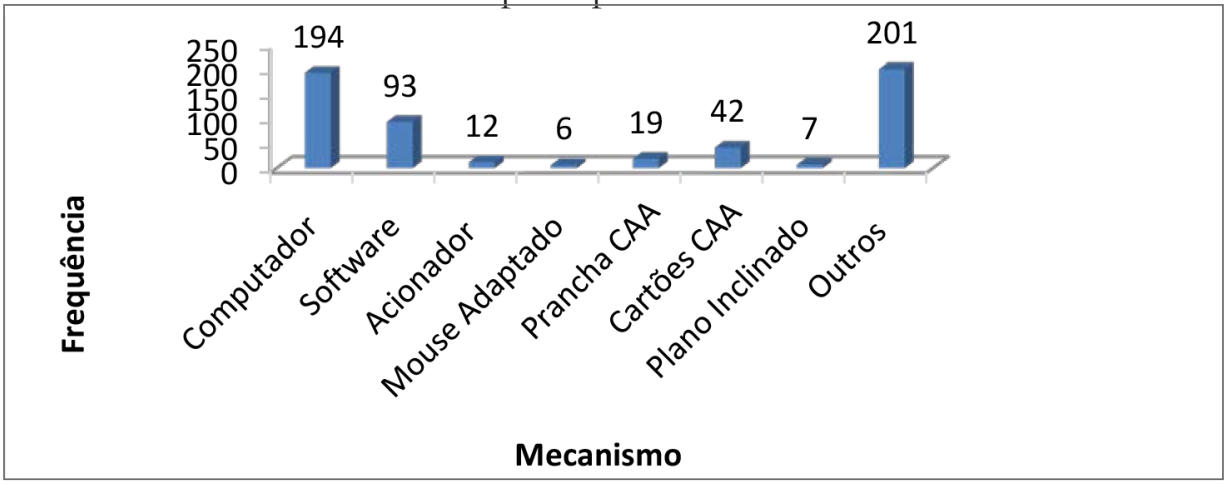

Computadores são os recursos mais usados pelas professoras em suas Salas de Recursos.

No quadro 2, estão listados todos os softwares indicados pelas professoras.

Quadro 2 - Softwares usados

\begin{tabular}{|l|c|}
\hline Software & Número de respondentes \\
\hline Boardmaker & 20 \\
\hline Alfa & 6 \\
\hline Participar & 11 \\
\hline Prancha Fácil & 1 \\
\hline Fono Tico & 1 \\
\hline Dosvox & 16 \\
\hline Aventuras & 19 \\
\hline Abc & 1 \\
\hline Educativo & 11 \\
\hline Pranchas Pedagógicas & 1 \\
\hline Contos Infantis 1 & 1 \\
\hline
\end{tabular}


No Quadro 3, estão listados os recursos classificados pelas professoras como "Outros".

Quadro 3 - Recursos classificados pelas professoras como "Outros"

\begin{tabular}{|c|c|}
\hline Recurso & Número de respondentes \\
\hline Libras & 3 \\
\hline Alfabeto em Libras & 2 \\
\hline Tablet & 26 \\
\hline Jogos educativos & 19 \\
\hline Jogos e materiais adaptados & 25 \\
\hline Jogos pedagógicos & 17 \\
\hline Lupa eletrônica & 2 \\
\hline Letras e números móveis e ampliados & 17 \\
\hline Programa Sebran & 9 \\
\hline Site estudamos.com & 6 \\
\hline Programa Pé de Vento & 4 \\
\hline Coleção Fono na Escola & 13 \\
\hline Brinquedos & 4 \\
\hline Pesquisa & 10 \\
\hline Gravuras variadas & 1 \\
\hline Miniaturas & 2 \\
\hline Jogos didáticos & 2 \\
\hline Material concreto & 14 \\
\hline Ampliação & 1 \\
\hline Material dourado & 1 \\
\hline Maquetes & 1 \\
\hline Materiais tridimensionais & 1 \\
\hline Brinquedos adaptados & 2 \\
\hline Brinquedos com acionador & 1 \\
\hline Caixa de antecipação & 1 \\
\hline Sistema de calendários & 1 \\
\hline Jogos & 3 \\
\hline Brincadeiras & 1 \\
\hline Oficinas de produção de texto & 2 \\
\hline
\end{tabular}




\begin{tabular}{|l|c|}
\hline Recurso & Número de respondentes \\
\hline Rodas de leitura & 1 \\
\hline Oficinas pedagógicas & 1 \\
\hline Calculadora & 1 \\
\hline Cartão com opção de resposta & 1 \\
\hline Letras móveis & 1 \\
\hline Figuras e palavras com velcro & 2 \\
\hline Conhecimentos matemáticos & 1 \\
\hline Mesa adaptada & 2 \\
\hline Caderno pedagógico adaptado & 1 \\
\hline Material diversificado & 1 \\
\hline Teclado adaptado & 7 \\
\hline Jogos online & 2 \\
\hline Atividades adaptadas & 1 \\
\hline História adaptada & 1 \\
\hline Adaptaçóes escritas & 6 \\
\hline Material adaptado & 4 \\
\hline Pasta de vocabulário & \\
\hline
\end{tabular}

Cento e sessenta em cinco, ou seja, 63\% do total de 262 alunos são atendidos nas 17 escolas onde estão lotadas as 17 professoras. Os demais (37\%) recebem atendimento em outras escolas (escolas extras). O número médio de escolas extras atendidas pelas professoras é três e a variação é de uma a seis escolas. 


\section{Discussão}

Os dados fornecidos pelas participantes acerca de seu perfil profissional mostram que se trata de um grupo relativamente jovem, mas com razoável tempo de magistério e de dedicação ao ensino da população-alvo da Educação Especial. Sua atuação, contudo, nas Salas de Recursos Multifuncionais é igual ou inferior a três anos. A maioria, quase absoluta, tem curso superior e, além disso, muitas delas frequentaram cursos de especialização. Todas, sem exceção, fizeram curso de Comunicação Alternativa antes de ingressar nesta pesquisa. Este foi um dos critérios para ser participante dessa formação. Muitas frequentam eventos na área e costumam ler sobre assuntos relacionados à educação do aluno especial.

A análise dos dados acerca dos alunos atendidos por essas professoras confirma muitas das conclusóes obtidas pelo conjunto de estudos desenvolvidos por 76 pesquisadores oriundos de 21 universidades localizadas em 38 municípios brasileiros. Com a participação de 596 professores das Salas de Recursos Multifuncionais, o projeto coordenado pela professora Enicéia Mendes, no Observatório Nacional de Educação Especial, foi iniciado em 2010 e finalizado em 2015 (Mendes et al., 2015).

No atual estudo, o número médio de alunos atendidos por docente é de 15 , com variação entre seis e 24 . No conjunto de estudos coordenados por Mendes et al. (2015), esse quantitativo variou entre um e 23. Corroborando os achados de Mendes, há, no presente estudo, predominância de alunos com deficiência intelectual. Essa concordância estende-se para as séries escolares dos alunos. Ou seja, são atendidos alunos desde o ensino infantil até o ensino médio, com maior representatividade de estudantes do ensino fundamental. Observe-se que a maioria dos atendimentos (63\%) é ofertada na própria escola onde as professoras estão lotadas. Contudo, todas elas deslocam-se para outros estabelecimentos escolares no âmbito de sua CRE para oferecer esse atendimento especializado.

A periodicidade dos encontros dos alunos com a professora da SRM é bastante semelhante àquela relatada por Mendes et al. (2015). Essa autora e colaboradores informam que os alunos pesquisados frequentavam de uma até cinco vezes por semana, com predomínio de dois atendimentos semanais. $\mathrm{Na}$ atual pesquisa, há uma variação entre um e quatro vezes, com maior frequência de dois atendimentos por semana. 
Outro aspecto em que houve concordância entre os estudos coordenados por Mendes et al. (2015) e a presente investigação diz respeito às atividades conduzidas nas SRM. Atividades ligadas à alfabetização, leitura e escrita ganharam destaque na agenda das professoras que ofertam atendimento educacional especializado, assim como o ensino de uso de hardwares, como computadores e tablets e softwares com jogos pedagógicos, materiais adaptados e atividades lúdicas.

Os dados coletados por meio dessa ficha dos alunos atendidos não permitem, infelizmente, concluir se as atividades conduzidas pelas professoras atendem ou não à orientação do MEC, que recomenda que o atendimento educacional especializado deva constituir-se como complementar ou suplementar ao ensino comum e não como substitutivo. 